\title{
APPLICATION OF RESPONSE SURFACE METHODOLOGY TO STUDY THE BIOLOGICAL REMOVAL OF NITROGEN FROM EFFLUENT OF CATTLE SLAUGHTERHOUSE IN A SEQUENCING BATCH REACTOR
}

\author{
ADRIANA N. DE LIMA ${ }^{1}$, BENEDITO M. GOMES ${ }^{2}$, SIMONE D. GOMES ${ }^{3}$, \\ KARINA Q. DE CARVALHO ${ }^{4}$, DIVAIR CHRIST ${ }^{5}$
}

\begin{abstract}
The aim of this study was to evaluate the efficiency of a sequencing batch reactor (SBR) on biological removal of nitrogen from cattle slaughterhouse wastewater by nitrification/denitrification processes. The effects of initial concentration of ammoniacal nitrogen were investigated at 100; 150 and $200 \mathrm{mg} \mathrm{L}^{-1}$ and air flow rate at $0.125 ; 0.375$ and $0.625 \mathrm{~L} \mathrm{~min}^{1} \mathrm{~L}_{\text {reactor }}{ }^{-1}$ on the nitrogen compounds removal, by a Central Composite Rotational Design (CCRD) configuration. There were variations from 9.2 to $94.9 \%, 4.0$ to $19.6 \%$ and 20.8 to $92.0 \%$ in the conversion of ammoniacal nitrogen to nitrate and nitrite concentration and removal of total nitrogen, respectively. The increase of air flow rate and decrease of the initial concentration of ammoniacal nitrogen resulted in higher efficiencies of total nitrogen removal, as well as the conversion of ammoniacal nitrogen to nitrate. During the pre-established intervals of this study, the removal and conversion efficiencies of nitrogen compounds above $85 \%$ were achieved in air flow rate variations from 0.375 to $0.725 \mathrm{~L} \mathrm{~min}^{-1} \mathrm{~L}_{\text {reactor }}{ }^{-1}$ and initial concentration of ammoniacal nitrogen from 80 to $200 \mathrm{mg} \mathrm{L}^{-1}$. On denitrification process, we obtained efficiencies from 91.5 to $96.9 \%$ on the removal of nitrite/nitrate and from 78.3 to $87.9 \%$ on the removal of organic matter.
\end{abstract}

KEYWORDS: nitrification, denitrification, central composite rotational design.

\section{APLICAÇÃO DA METODOLOGIA DE SUPERFÍCIE DE RESPOSTA NO ESTUDO DA REMOÇÃO BIOLÓGICA DE NITROGÊNIO DE EFLUENTE DE ABATEDOURO BOVINO EM REATOR EM BATELADA SEQUENCIAL}

RESUMO: O objetivo do trabalho foi avaliar a eficiência de um reator em batelada sequencial (RBS) na remoção biológica de nitrogênio de efluente de abatedouro bovino, por meio dos processos de nitrificação/desnitrificação. Foram investigados os efeitos da concentração inicial de nitrogênio amoniacal de 100; 150 e $200 \mathrm{mg} \mathrm{L}^{-1}$ e vazão de ar de 0,125; 0,375 e $0,625 \mathrm{~L} \mathrm{~min}^{-1} \mathrm{~L}_{\text {reator }}^{-1}$ na remoção de compostos nitrogenados, por meio de configuração de um planejamento do tipo Delineamento Composto Central Rotacional (DCCR). Foram verificadas variações de 9,2 a 94,9\%, 4,0 a 19,6\% e 20,8 a 92,0\% na conversão de nitrogênio amoniacal a nitrato, acúmulo de nitrito e remoção de nitrogênio total, respectivamente. O aumento da vazão de ar e a diminuição da concentração inicial de nitrogênio amoniacal resultaram em maiores eficiências na remoção de nitrogênio total e na conversão de nitrogênio amoniacal a nitrato. Nos intervalos preestabelecidos do estudo, eficiências de remoção e conversão dos compostos nitrogenados, superiores a 85\%, foram atingidas com variação de vazão de ar de 0,375 a $0,725 \mathrm{~L} \mathrm{~min}^{-1} \mathrm{~L}_{\text {reator }}{ }^{-1}$ e concentração inicial de nitrogênio amoniacal de 80 a $200 \mathrm{mg} \mathrm{L}^{-1}$. No processo de desnitrificação, foram obtidas eficiências de 91,5 a 96,9\% na remoção de nitrito/nitrato e de 78,3 a 87,9\% na remoção de matéria orgânica.

PALAVRAS-CHAVE: nitrificação, desnitrificação, delineamento composto central rotacional.

\footnotetext{
${ }^{1}$ Tecnóloga Ambiental, Doutoranda em Eng. Agrícola, Programa de Pós-graduação em Engenharia Agrícola, UNIOESTE/CascavelPR, Fone: (46) 3232-1099, adriilima@hotmail.com

${ }^{2}$ Eng ${ }^{\mathbf{0}}$ Agrícola, Prof. Associado, Centro de Ciências Exatas e Tecnológicas, UNIOESTE, Cascavel - PR, benedito.gomes@unioeste.br

${ }^{3}$ Eng $^{\mathrm{a}}$ Agrônoma, Profa. Associada, Centro de Ciências Exatas e Tecnológicas, UNIOESTE, Cascavel - PR, simoned@unioeste.br

${ }^{4}$ Eng ${ }^{\underline{a}}$ Civil, Profa. Adjunta, Depto. Acadêmico de Construção Civil, UTFPR, Curitiba - PR, kaquerne@utfpr.edu.br

${ }^{5}$ Eng ${ }^{0}$ Agrícola, Prof. Adjunto, Centro de Ciências Exatas e Tecnológicas, UNIOESTE, Cascavel - PR, divair.christ@unioeste.br Recebido pelo Conselho Editorial em: 16-1-2013

Aprovado pelo Conselho Editorial em: 4-12-2013
} 


\section{INTRODUCTION}

Slaughterhouses have significant importance in the economic and social development, as these activities generate direct jobs and involve other sectors, ranging from the rearing and slaughter of animals and sale of inputs to the commercialization of meat and its byproducts.

There is a concern about the environmental impact of these activities due to the high consumption of water from the slaughter and disinfection of facilities, equipment, resulting in high effluent generation (DALLAGO et al., 2012).

Effluents from the meat processing are characterized by high levels of organic compounds, nutrients, solids, oils and greases (THEBALDI et al., 2011). The adequacy of the characteristics of these effluents to discharge standards, determined by law, is indispensable due to the environmental aggravating and problems related to public health. In general, the technologies employed in the treatment of these effluents are efficient in removing settleable solids and carbonaceous organic matter, but they have shortcomings in the leaching of nutrients, particularly nitrogen in its different forms.

The discharge of effluents containing nitrogenous compounds in water bodies can cause eutrophication, with adverse effects such as algal blooms, decreased dissolved oxygen, toxin formation, problems of generating odors and fish kills (KUMMER et al., 2011). The water bodies in contact with these compounds are subject to excessive reproduction of cyanobacteria able to synthesize toxic substances causing adverse effects to human health as gastroenteritis and hepatoenteritis, when present in water used for human consumption (SANTOS et al., 2010).

Conventionally, the removal of nitrogen from agroindustrial effluents is performed by biological processes that include nitrification followed by denitrification, separated in different reactors or different ranges of aeration. The integration of these processes into a single processing system with operating mode divided into cycles is a specific characteristic of the sequencing batch reactor (SBR).

The operational flexibility and the possibility of joint removal of organic compounds and nitrogen are the main advantages of SBR (OLIVEIRA \& SANTANA, 2011). Despite the proven efficiency, biological removal of nitrogen in SBR is influenced by a number of factors that can affect the processes of nitrification and denitrification, including temperature, $\mathrm{pH}$, redox potential, alkalinity, salinity, oxygen and substrate concentration, carbon/nitrogen relation, hydraulic retention time and cell retention time (MENG et al., 2008; HU et al., 2009).

Within this context, the aim of this study was to evaluate the effects of the initial concentration of ammoniacal nitrogen and air flow rate in biological removal of nitrogen from effluent of cattle slaughterhouse in SBR, using the central composite rotational design (CCRD).

\section{MATERIAL AND METHODS}

The substrate used in the experiment feeding was effluent from anaerobic lagoon of a cattle slaughterhouse located in Toledo city - state of Paraná (PR), in Brazil, located at $24^{\circ} 46^{\prime} 00^{\prime \prime} \mathrm{S}$ and $53^{\circ} 45^{\prime} 22$ " O. It is estimated that about $60,000 \mathrm{~L} \mathrm{~d}^{-1}$ of effluent are generated in the slaughter process and other hygiene activities carried out in the slaughterhouse. Effluent samples showed values of physicochemical composition of: $\mathrm{pH}=7.8 \pm 0.4$; total alkalinity $=400.0 \pm 14.4 \mathrm{mg} \mathrm{CaCO}_{3} \mathrm{~L}^{-1}$; chemical oxygen demand $(\mathrm{COD})=420.8 \pm 79.8 \mathrm{mg} \mathrm{L}^{-1}$; dissolved oxygen $=0.6 \pm 0.1 \mathrm{mg} \mathrm{L}^{-1}$; total Kjeldahl nitrogen $=255.6 \pm 55.7 \mathrm{mg} \mathrm{L}^{-1}$; ammoniacal nitrogen $=238.0 \pm 44.9 \mathrm{mg} \mathrm{L}^{-1}$; nitrite $=2.6$ $\pm 2.4 \mathrm{mg} \mathrm{L}^{-1}$ and nitrate $=4.2 \pm 0.9 \mathrm{mg} \mathrm{L}^{-1}$.

The experimental apparatus included nitrification followed by denitrification in a sequencing batch reactor (SBR) made of polyethylene, with $185 \mathrm{~mm}$ of diameter and $205 \mathrm{~mm}$ of high, with working volume of $4 \mathrm{~L}$. The operating cycle of SBR was of 24h, with $16 \mathrm{~h}$ for aerobic reaction; $6 \mathrm{~h}$ 
for anoxic reaction; $1 \mathrm{~h}$ for sedimentation; $0.1 \mathrm{~h}$ for disposal of effluent and $0.9 \mathrm{~h}$ for rest and preparation for the next batch.

The aeration system, of the aerobic reaction phase, consisted of an aquarium aerator Big-Air; model A420, coupled to a flow meter to control the air flow rate. The air was circulated into the reactor through two porous stones. In the anoxic phase reaction, a mechanical mixer with rotating blades around $25 \mathrm{rpm}$ was used to keep the effluent in constant contact with the biomass.

On the disposal of the effluent, created by siphoning, we kept $25 \%$ of sedimented sludge referring to the inoculum for the next batch. We fixed the concentration of volatile suspended solids at $10,000 \mathrm{mg} \mathrm{L}^{-1}$ in the sludge of the reactor, at the beginning of each batch to be tested. The concentration of suspended solids was determined according to the methodology described by DAMASCENO et al. (2003) with trace of a standard curve of the optical density versus the concentration of total suspended solids.

The alkalinity correction in the aerobic phase was performed by the addition of sodium bicarbonate $\left(\mathrm{NaHCO}_{3}\right)$ to maintain the alkalinity $/ \mathrm{N}^{-\mathrm{NH}_{4}}{ }^{+}$ratio higher than the stoichiometry of $7.14 \mathrm{mg}$ of $\mathrm{CaCO}_{3}$ per mg of oxidized ammonia, whereas $1 \mathrm{~g}$ of alkalinity as $\mathrm{CaCO}_{3}$ is equivalent to $1.22 \mathrm{~g} \mathrm{HCO}_{3}{ }^{-}$. In the initial phase of the denitrification process, the $\mathrm{COD} / \mathrm{N}_{\text {total }}$ ratio was adjusted to 5 with addition of ethanol.

To verify the influence of the air flow rate $\left(Q_{\text {air }}\right)$ and initial concentration of ammoniacal nitrogen ([ ] $\mathrm{i} \mathrm{N}_{\mathrm{ammon}}$ ) factors in the removal of nitrogen in the effluent from cattle slaughterhouse, we elaborated a central composite rotational design (CCRD), star type $\left(\alpha=45^{\circ}\right)$, comprising factorial $\left(2^{2}\right)$ with levels $(-1$ and +1$)$, axial points $(-1.414$ and +1.414$)$ and three replicates at the center point (0), which resulted in 11 trials. The experiments were conducted in random order to not introduce systematic analysis of data errors. The levels of the analyzed factors are presented in Table 1.

TABLE 1. Levels of the experimental factors applied in the experimental delineation.

\begin{tabular}{|c|c|c|c|c|c|c|}
\hline \multirow{2}{*}{\multicolumn{2}{|c|}{ Factorial experiments/Unit }} & \multicolumn{5}{|c|}{ Coded variables } \\
\hline & & $-\alpha$ & -1 & 0 & +1 & $+\alpha$ \\
\hline Factor 1 & $\mathrm{Q}_{\text {air }}\left(\mathrm{L} \cdot \mathrm{min}^{-1} \cdot \mathrm{L}_{\text {reactor }}{ }^{-1}\right)$ & 0.025 & 0.125 & 0.375 & 0.625 & 0.725 \\
\hline Factor 2 & [ ] $\mathrm{i} \mathrm{N}_{\mathrm{ammon}}\left(\mathrm{mg} \cdot \mathrm{L}^{-1}\right)$ & 80 & 100 & 150 & 200 & 220 \\
\hline
\end{tabular}

The response variables assessed were the conversion of ammoniacal nitrogen to nitrate and the nitrite accumulation in the nitrification process and the removal of total nitrogen in the complete process (nitrification/denitrification).

The performance evaluation of the experimental unit was based on monitoring the samples collected in the initial and final stage of the process. The parameters determined were $\mathrm{pH}(4500 \mathrm{~A})$, total alkalinity (2320 B), chemical oxygen demand (D 5220), dissolved oxygen (4500-O G), total Kjeldahl nitrogen $(4500 \mathrm{C})$, ammoniacal nitrogen (4500 F), nitrite $\left(4500 \mathrm{NO}_{2} \mathrm{I}\right)$ and nitrate (4500 NO 3 I) according to procedures described in Standard Methods for the Examination of Water and Wastewater (APHA, 1998). The concentrations of free ammonia and nitrous acid were estimated as a function of $\mathrm{pH}$, temperature and concentrations of ammoniacal nitrogen and nitrite, by applying equations presented by ANTHONISEN et al. (1976).

The determination of the effects of independent variables, regression coefficients, analysis of variance (ANOVA) and the obtainment of the graphics of surface response, at $10 \%$ level of significance were performed on a computational tool.

The experimental validations of the proposed models were performed in quintuplicate based on process conditions that provided the desired characteristics in the final effluent of the reactor. 


\section{RESULTS AND DISCUSSION}

Table 2 shows the component values of the experimental design matrix and the responses regarding the conversion of ammoniacal nitrogen to nitrate and nitrite accumulation in the nitrification process and the removal of total nitrogen in the complete process in the tests performed.

TABLE 2. Planning Matrix (CCRD) with the real factors and results obtained in the conversion of ammoniacal nitrogen to nitrate, nitrite accumulation and removal of total nitrogen (\%).

\begin{tabular}{|c|c|c|c|c|c|}
\hline \multirow{3}{*}{ Tests } & \multicolumn{2}{|c|}{ Real levels of factors } & \multicolumn{3}{|c|}{ Response variables } \\
\hline & \multirow{2}{*}{$\begin{array}{c}\mathrm{Q}_{\text {air }} \\
\left(\mathrm{L}^{-\mathrm{min}^{-1}}{ }^{-1} \text { Lreactor }^{-1}\right)\end{array}$} & \multirow{2}{*}{$\begin{array}{l}\text { [ ]i N } \mathrm{ammon}_{\text {ammon }} \\
\left(\mathrm{mg}^{-1} \mathrm{~L}^{-1}\right)\end{array}$} & \multicolumn{2}{|c|}{$\begin{array}{l}\text { Nitrification } \\
\text { Process }\end{array}$} & \multirow{2}{*}{$\begin{array}{c}\text { Complete } \\
\text { Process } \\
\text { NT removal (\%) }\end{array}$} \\
\hline & & & $\begin{array}{c}\mathrm{N}_{\text {ammon }} \text { conversion } \\
\text { to } \mathrm{NO}_{3}^{-}(\%)\end{array}$ & $\begin{array}{c}\mathrm{NO}_{2}^{-} \text {accumulation } \\
(\%)\end{array}$ & \\
\hline 1 & 0.125 & 100 & 38.4 & 14.1 & 55.9 \\
\hline 2 & 0.625 & 100 & 94.0 & 4.0 & 91.0 \\
\hline 3 & 0.125 & 200 & 31.2 & 19.6 & 48.4 \\
\hline 4 & 0.625 & 200 & 64.2 & 11.0 & 66.1 \\
\hline 5 & 0.375 & 150 & 94.9 & 3.6 & 90.5 \\
\hline 6 & 0.375 & 150 & 93.9 & 4.0 & 90.7 \\
\hline 7 & 0.375 & 150 & 94.2 & 4.7 & 91.0 \\
\hline 8 & 0.375 & 80 & 90.8 & 10.6 & 92.0 \\
\hline 9 & 0.375 & 220 & 63.6 & 9.5 & 64.8 \\
\hline 10 & 0.025 & 150 & 9.2 & 7.6 & 20.8 \\
\hline 11 & 0.725 & 150 & 94.3 & 3.6 & 90.4 \\
\hline
\end{tabular}

In Pareto charts are shown the linear (L) and quadratic (Q) effects of the factors and their interaction. The effects with values located to the right of the dashed line were significant at $10 \%$ level of significance (Figure 1).

The initial concentration of ammoniacal nitrogen (L and $\mathrm{Q}$ ) and air flow rate (L) factors presented a negative effect on the conversion of ammoniacal nitrogen to nitrate and total nitrogen removal. This indicates that the increase in any of these variables, within the ranges studied, resulted in reducing efficiencies. The effect of air flow rate (Q) had a positive influence, i.e. the increase of this variable caused increasing efficiency. The effect of air flow rate was greater than the effect of the initial concentration of ammoniacal nitrogen. Linear and quadratic effects of initial concentration of ammoniacal nitrogen were close in absolute value. In the accumulation of nitrite, the initial ammoniacal nitrogen concentration (Q) had a significant positive effect while the air flow rate (L) exerted significant negative effect. This means that increasing the initial concentration of ammoniacal nitrogen and decreasing the air flow rate caused greater accumulation of nitrite in the nitrification process. The interaction between factors was not significant for any of the response variables evaluated.

From the factors that exerted significant influence on the response variables, we obtained mathematical eqs. (1; 2 and 3) of the quadratic regression models that best adjusted to the experimental data.

$$
\begin{aligned}
& \text { Conv. } \mathrm{N}_{\text {ammon }} \text { to } \mathrm{NO}_{3}{ }^{-}(\%)=94.35+26.15 \mathrm{Q}_{\mathrm{air}}-23.28 \mathrm{Q}_{\mathrm{air}}{ }^{2}-9.43[] \mathrm{iN}_{\mathrm{ammon}}-10.46\left[\mathrm{iN}_{\mathrm{Amon}}{ }^{2}\right. \\
& \mathrm{NO}_{2}{ }^{-} \text {accumulation }(\%)=5.80-3.06\left(\mathrm{Q}_{\text {air }}\right)+3.55\left[\mathrm{iN}_{\mathrm{Amon}}{ }^{2}\right. \\
& \mathrm{NT} \text { removal }(\%)=90.77+18.90 \mathrm{Q}_{\mathrm{air}}-18.07 \mathrm{Q}_{\mathrm{air}}{ }^{2}-8.88\left[\mathrm{iN}_{\mathrm{Ammon}}-6,58[]_{\mathrm{iN}} \mathrm{Amon}^{2}\right.
\end{aligned}
$$




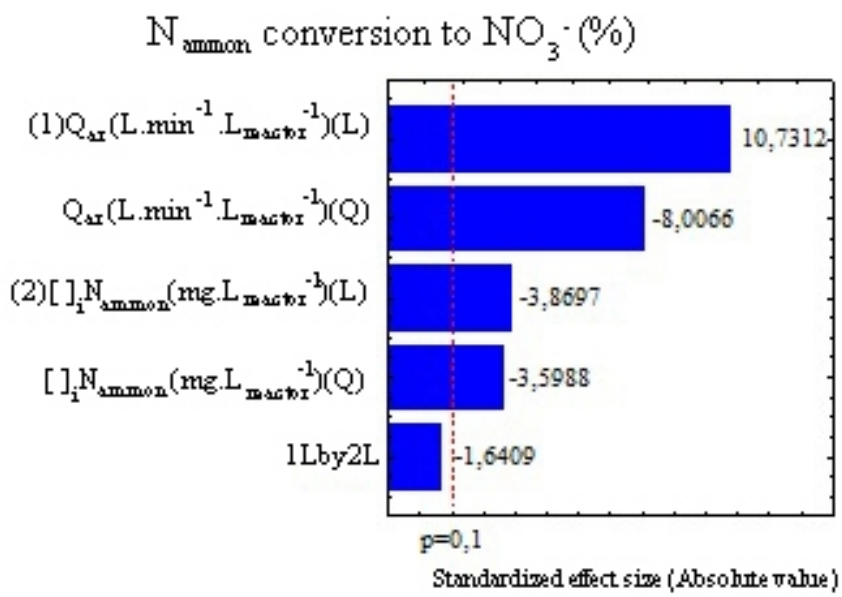

(a)
$\mathrm{NO}_{2}{ }^{-}$accumulation $(\%)$

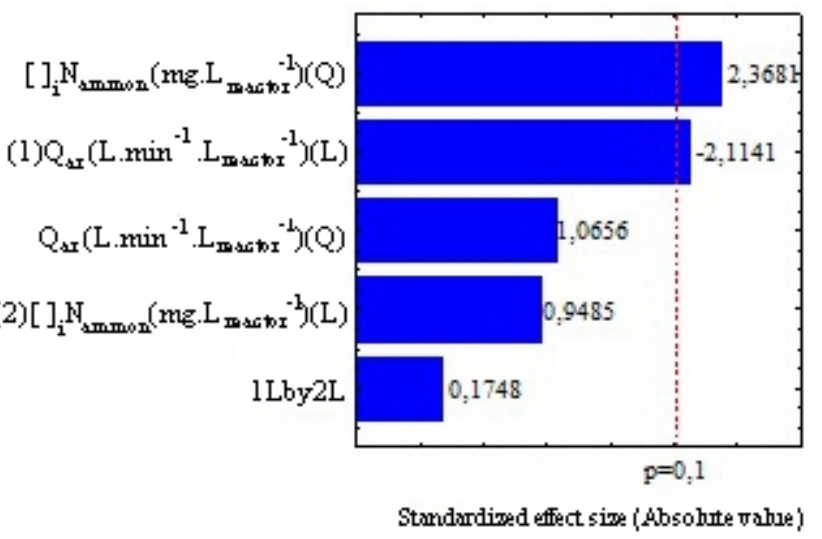

(b)

TN removal efficiency $(\%)$

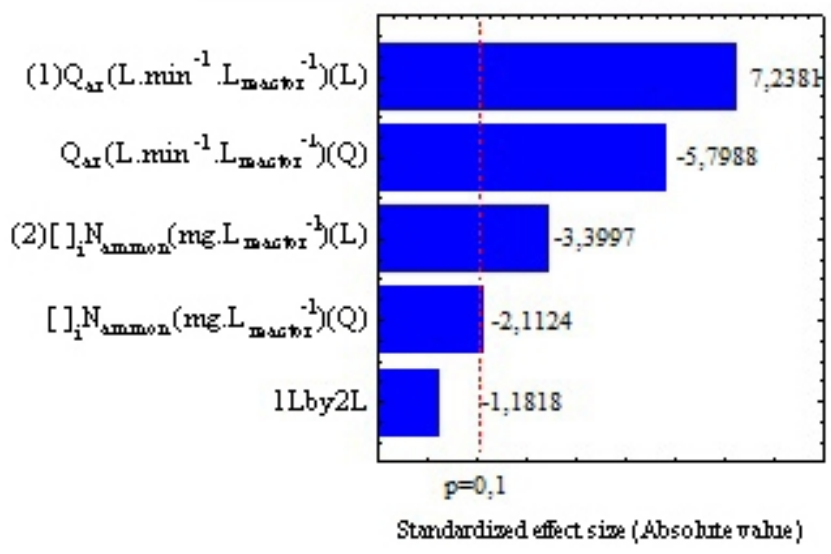

(c)

FIGURE 1. Pareto chart for the (a) conversion of ammoniacal nitrogen to nitrate, (b) nitrite accumulation and (c) removal of total nitrogen (\%).

The quadratic regression models presented describe the observed variations in data conversion efficiency of ammoniacal nitrogen to nitrate, nitrite accumulation and removal of total nitrogen in 96.2, 56.2 and $93.8 \%$, respectively, at $10 \%$ of significance. To verify the adequacy of the models to experimental data, analysis of variance (ANOVA) were performed and, from the results presented in these analyzes, we found that the regression models presented significant and predictive values for the response variables analyzed in the range of $90 \%$ of confidence. $F_{\text {calculated }}$ values of 38.215 (conversion of ammoniacal nitrogen to nitrate), 5.149 (nitrite accumulation) and 22.916 (removal of total nitrogen) are higher than the values of $F_{\text {tabulated }(4 ; 6 ; 0,10)}$ of $3.180, F_{\text {tabulated }(2 ; 8 ; 0,10)}$ of 3.113 and $\mathrm{F}_{\text {tabulated }(4 ; 6 ; 0,10)}$ of 3.180, respectively.

Figure 2 shows the results regarding the behavior of the process for (a) conversion of ammoniacal nitrogen to nitrate and (b) accumulation of nitrite in the nitrification process (\%) through the contour graphics. 
$\mathrm{N}_{\text {ammon }}$ conversion to $\mathrm{NO}_{3} \cdot(\%)$

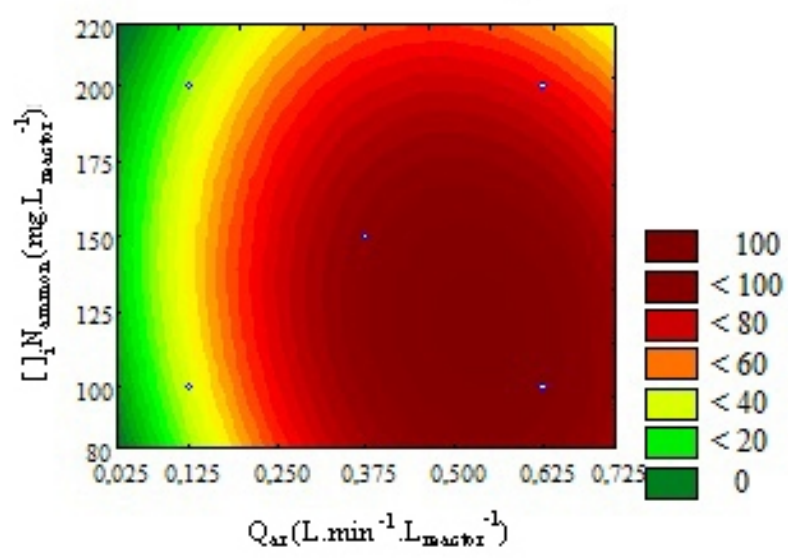

(a)

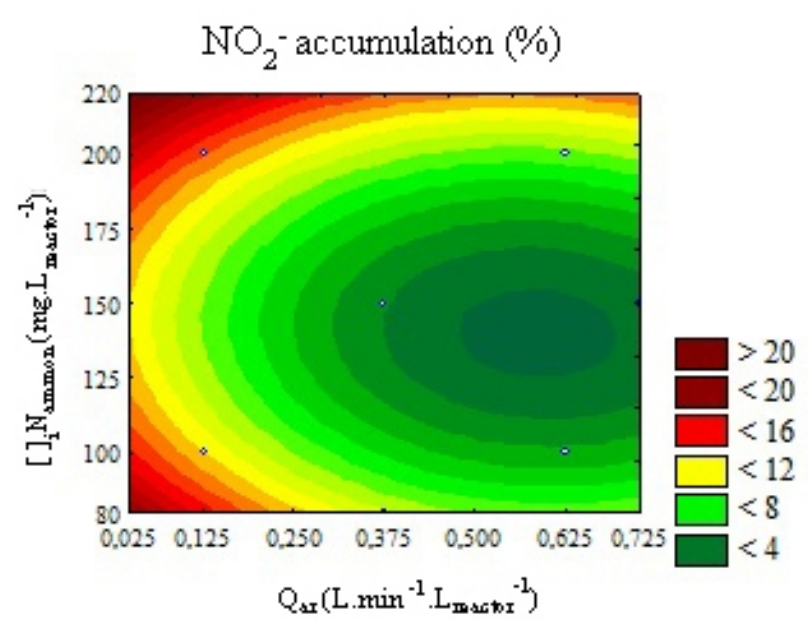

(b)

FIGURE 2. Graphics of contour for the (a) conversion of ammoniacal nitrogen to nitrate and (b) nitrite accumulation in the nitrification process (\%).

It was possible to ascertain the existence of an optimal range for each factor and the combination of these ranges. The increased air flow rate and decreased initial concentration of ammoniacal nitrogen resulted in greater efficiencies in removal of total nitrogen and conversion of ammoniacal nitrogen to nitrate and less nitrite accumulation. The behavior of the process for the removal efficiency of total nitrogen in the complete process is presented through the response surface graph in Figure 3.

The efficiencies in the conversion of ammoniacal nitrogen to nitrate and nitrite accumulation in nitrification and total nitrogen removal process in the complete process presented variations from 9.2 to $94.9 \%, 4.0$ to $19.6 \%$ and 20.8 to $92.0 \%$ respectively. Within the pre-established ranges of the study, removal efficiencies and nitrogen conversion higher than $85 \%$ and nitrite accumulation less than $8 \%$ were achieved in air flow rate levels from 0.375 to $0.725 \mathrm{~L} \mathrm{~min}^{-1} \mathrm{~L}_{\text {reactor }}{ }^{-1}$ and initial ammoniacal nitrogen concentration between 80 and $200 \mathrm{mg} \mathrm{mg} \mathrm{L}^{-1}$. The increase of efficiencies in relation to the air flow rate may be related to the dissolved oxygen concentration, higher than $2 \mathrm{mg} \mathrm{L}^{-1}$, available to the nitrifying activity, provided by air flow rates higher than $0.375 \mathrm{~L} \mathrm{~min}^{-1} \mathrm{~L}_{\text {reator }}{ }^{-1}$.

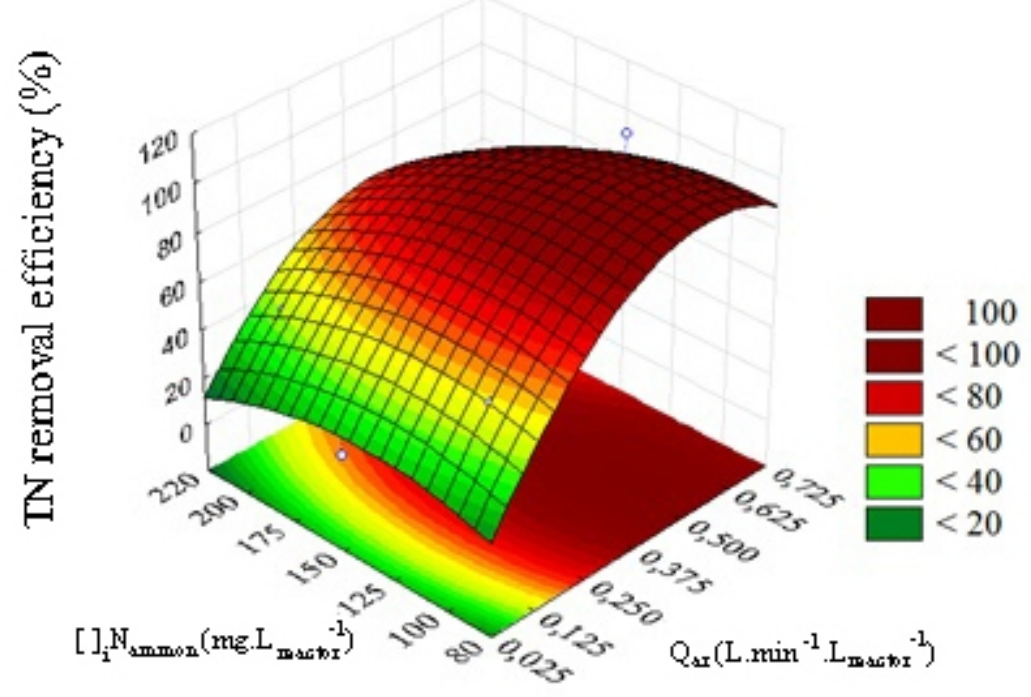

FIGURE 3. Response surface to the removal of total nitrogen in the nitrification/denitrification complete process (\%). 
According to KARGI \& MOO-YOUNG (1985), in many aerobic systems, the availability of oxygen to the micro-organisms depends on the mass transfer. Due to the low solubility of oxygen dissolved in water, the velocity of oxygen transfer from the bubble until the cells may be the limiting factor, which determines the velocity of the biological conversion. This may explain the fact that no significant differences in the removal and conversion of nitrogen compounds with higher air flow rates at $0.375 \mathrm{~L} \mathrm{~min}^{-1} \mathrm{~L}_{\text {reator }}{ }^{-1}$.

Similar results to this study were obtained by ANDRADE et al. (2010) that assessed the performance of a sequencing batch reactor with working volume of $2.5 \mathrm{~L}$, in the nitrification of anaerobic effluent from fish processing, operated with reaction time of $24 \mathrm{~h}$. The authors obtained maximum efficiency of $85.6 \pm 0.6 \%$ for combination of initial ammoniacal nitrogen concentration of $70 \mathrm{mg} \mathrm{L}^{-1}$ and air flow rate of $2 \mathrm{~L} \mathrm{~min}^{-1} \mathrm{~L}_{\text {reator }}{ }^{-1}$, i.e., optimal operating condition.

ZENATTI et al. (2009) evaluated the effectiveness of a sequencing batch reactor with immobilized biomass and working volume of 2.5L, in the treatment of wastewater from tilapia processing. The maximum conversion efficiency of $81.9 \pm 3.8 \%$ was achieved when the reactor was operated with air flow rate of $6 \mathrm{~L} \mathrm{~min}^{-1} \mathrm{~L}_{\text {reator }}{ }^{-1}$ and reaction time of $12 \mathrm{~h}$ in the aerobic phase.

From the analysis of the surface responses, it was possible to determine the process conditions that provided the desired characteristics in the reactor effluent, based on the product and processes involved. Such conditions were the combination of the initial ammoniacal nitrogen concentration of $200 \mathrm{mg} \mathrm{L}^{-1}$ and air flow rate of $0.5 \mathrm{~L} \mathrm{~min}^{-1} \mathrm{~L}_{\text {reator }}{ }^{-1}$ used in the obtained validation models.

In the models validation, the removal of total nitrogen efficiency in the complete process, the conversion of ammoniacal nitrogen to nitrate and nitrite accumulation in the nitrification process were $87.4 \pm 2.8 \%$ (CV 1.03\%), $85.3 \pm 1.5 \%$ (CV 2.8\%) and $7.9 \pm 0.3 \%$ (4.6\% CV), respectively, similar to the predicted results by the models of $94.2 ; 77.3$ and $6.2 \%$. The differences between prediction and experimental results can be attributed to the reparametrization of models. The coefficient of variation less than $20 \%$ indicated the homogeneity of the obtained experimental data and the ability to reproducibility of the process.

The ammoniacal nitrogen concentration in the effluent of $12.3 \pm 1.1 \mathrm{mg} \mathrm{L}^{-1}$ obtained at the end of the validation trials met the maximum limit determined as standard for effluent discharge of $20 \mathrm{mg} \mathrm{L}^{-1}$ in CONAMA Resolution 430/2011 (BRASIL, 2011).

The use of ethanol as a carbon source was satisfactory in the denitrification process. The efficiency in the removal of nitrite + nitrate and COD in the denitrification presented variations from 91.5 to $96.7 \%$ and from 78.3 to $87.9 \%$, respectively.

The results of the $\mathrm{pH}$ and alkalinity parameters indicated expected behavior in the processes of nitrification and denitrification, showing alkalinity consumption and production, respectively. The relation alkalinity consumed $/ \mathrm{N}_{\text {ammoniacal oxidized }} 6.5 \pm 0.4$ in the nitrification process remained below the theoretical value of $7.14 \mathrm{mgCaCO}_{3} \mathrm{mg} \mathrm{N}^{-1}$ required for nitrification of ammoniacal nitrogen. Despite presenting real stoichiometric value less than the theoretical, alkalinity was not considered a limiting parameter in the nitrification process. In the denitrification we observed a recovery of 44.1 $\pm 2.6 \%$ of the alkalinity consumed in the nitrification process. Maximum concentrations of free ammonia and nitrous acid, in the order of 13.8 and $6.8 \times 10^{-9} \mathrm{mg} \mathrm{L}^{-1}$, respectively, did not inhibit the oxidation of ammoniacal nitrogen.

\section{CONCLUSIONS}

The SBR system proved viable in the post-treatment of anaerobic effluent from cattle slaughterhouse in terms of removing nitrogenous compounds. The evaluated factors, initial ammoniacal nitrogen concentration and air flow rate, presented significant effects at $10 \%$ of significance in the processes of nitrification and nitrification/denitrification. 
The highest percentage of removal and conversion of nitrogen compounds, exceeding $85 \%$ and the lesser accumulation of nitrite levels were achieved in the air flow rate from 0.375 to $0.725 \mathrm{~L} \mathrm{~min}^{-1} \mathrm{~L}_{\text {reator }}{ }^{-1}$ and initial concentration of ammoniacal nitrogen from 80 to $200 \mathrm{mg} \mathrm{L}^{-1}$. The obtained regression models presented statistical and predictive significance for the variable responses analyzed.

\section{REFERENCES}

APHA - AMERICAN PUBLIC HEALTH ASSOCIATION; AWWA - AMERICAN WATER WPCF - WORKS ASSOCIATION; WATER ENVIRONMENT FEDERATION. Standard methods for the examination of water and wastewater. $20^{\text {th }} \mathrm{ed}$. Washington, 1998.

ANDRADE, L.; KUMMER, A.C.B.; FAZOLO, A.; DAMASCENO, S.; HASAN, S.D.M. Influência de nitrogênio amoniacal e vazão de ar no processo de nitrificação, etapa de tratamento de efluente de abatedouro de peixe. Engenharia Agrícola, Jaboticabal, v.30, n.1, p.160-7, Jan/Fev. 2010.

ANTHONISEN, A.C.; LOHER, R.C.; PRAKASAM, T.B.S.; SRINATH, E. Inhibition of nitrification by ammonia and nitrous acid. Journal of Water Pollution Control Federation, New York, v.48, n.5, p.835-52, mai. 1976.

BRASIL. Ministério do Meio Ambiente. CONAMA. Resolução no 411, de 13 de maio de 2011. Dispõe sobre as condições e padrões de lançamento de efluentes, complementa e altera a Resolução $\mathrm{n}^{\circ}$ 357, de 17 de março de 2005, do Conselho Nacional do Meio Ambiente-CONAMA. Diário Oficial da União, Brasilia-DF, 16 maio 2011. n.92, p.89-98.

DALLAGO, R.; DAMASCENO, S.; MEES, J.B.R.; ASSIS, T.M.; HASAN, S.D.M.; KUNZ, A. Nitrification and denitrification of a poultry slaughterhouse wastewater according to cycle time and ammoniacal nitrogen concentration using surface response methodology. International Journal of Food, Agriculture and Environment, Helsinki, v.10, n.2, p.856-60, ago. 2012.

DAMASCENO, S.; CEREDA, M.P.; PASTORE, G.M.; OLIVEIRA, J.G. Production of volatile compounds by Geotrichum fragrans using cassava wastewater as substrate. Process Biochemistry, Inglaterra, v.39, n.4, p.411-4, dez. 2003.

HU, J.; LI, D.; LIU, Q.; TAO, Y.; HE, X.; WANG, X.; LI, X. GAO, P. Effect of organic carbon on nitrification efficiency and community composition of nitrifying biofilms. Journal of Environmental Sciences, Beijing, v.21, n.3, p.387-94, mar. 2009.

KARGI, F.; MOO-YOUNG, M. Transport phenomena in bioprocess. Comprehensive Biotechnology, Oxford, v. 2, n.1, p.5-56, 1985.

KUMMER, A.C.B.; ANDRADE, L.; DAMASCENO, S.; FAZOLO, A.; HASAN, S.D.M.;

MACHADO, F. Tratamento de efluente de abatedouro de tilápia com adição de manipueira na fase anóxica. Engenharia Agrícola, Jaboticabal, v.31, n.1, p.150-7, jan./fev. 2011.

MENG, Q.; YANG, F.; LIU, L.; MENG, F. Effects of COD/N ratio and DO concentration on simultaneous nitrification and denitrification in an airlift internal circulation membrane bioreactor. Journal of Environmental Sciences, Beijing, v.20, n.8, p. 933-9, jul. 2008.

OLIVEIRA, R.A.; SANTANA, A.M. Tratamento de águas residuárias de suinocultura em reatores anaeróbios de fluxo ascendente com manta de lodo (UASB) em dois estágios seguidos de reator operado em batelada sequencial (RBS). Engenharia Agrícola, Jaboticabal, v.31, n.1, p.178-92, jan/fev. 2011. 
SANTOS, C.E.D.; TÉRAN, F.J.C.; VASCONCELOS, J.H.A., LUCAS, M.C. Remoção anaeróbia de nitrogênio amoniacal por meio de reator com cultura fixa em meio suporte operando em batelada sequencial. Engenharia Ambiental, Espírito Santo do Pinhal, v.7, n.2, p.190-203, abr./jun. 2010.

THEBALDI, M.S.; SANDRI, D.; FELISBERTO, A.B.; ROCHA, M.S.; NETO, S.A. Qualidade da água de um córrego sob influência de efluente tratado de abate bovino. Revista Brasileira de Engenharia Agrícola \& Ambiental, Campina Grande, v.15, n.3, p.302-309, mar. 2011.

ZENATTI, D.C.; DAMASCENO, S.; FAZOLO, A.; COSTANZI, R.N.; HASAN, S.D.M.; GENTELINI, A.L. Nitrificação de efluente de abatedouro de tilápia. Revista Brasileira de Engenharia Agrícola e Ambiental, Campina Grande, v.13, n.6, p.750-4, nov./dez. 2009. 